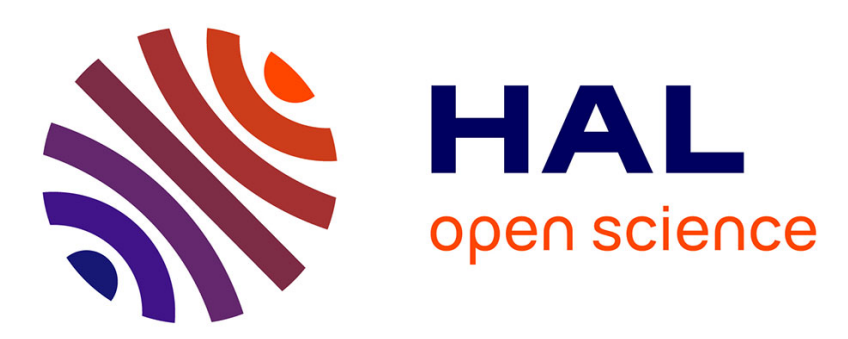

\title{
Ileal-J-Pouch Volvulus After Restorative Proctocolectomy
}

Lisa Corbiere, Véronique Desfourneaux, Aude Merdrignac

\section{To cite this version:}

Lisa Corbiere, Véronique Desfourneaux, Aude Merdrignac. Ileal-J-Pouch Volvulus After Restorative Proctocolectomy. Journal of Gastrointestinal Surgery, 2021, 25 (1), pp.325-326. 10.1007/s11605-02004630-6 . hal-02634586

\section{HAL Id: hal-02634586 https://hal-univ-rennes1.archives-ouvertes.fr/hal-02634586}

Submitted on 17 Jun 2020

HAL is a multi-disciplinary open access archive for the deposit and dissemination of scientific research documents, whether they are published or not. The documents may come from teaching and research institutions in France or abroad, or from public or private research centers.
L'archive ouverte pluridisciplinaire $\mathbf{H A L}$, est destinée au dépôt et à la diffusion de documents scientifiques de niveau recherche, publiés ou non, émanant des établissements d'enseignement et de recherche français ou étrangers, des laboratoires publics ou privés. 


\section{1 lleal-J-pouch volvulus after restorative proctocolectomy}

2 L. Corbière, MD ${ }^{1}$, V. Desfourneaux, $M D^{1}$, A. Merdrignac, MD, $\mathrm{PhD}^{2}$.

$3{ }^{1}$ Department of hepatobiliary and digestive surgery, 2 rue Henri Le Guilloux, CHU Rennes, Rennes,

4 France.

$5{ }^{2}$ Department of hepatobiliary and digestive surgery, Inserm, Institut NuMeCan (Nutrition Metabolism and

6 Cancer), University of Rennes, 2 rue Henri Le Guilloux, CHU Rennes, Rennes, France.

8 Corresponding author :

9 Dr Aude Merdrignac

10 Service de chirurgie hépatobiliaire et digestive

11 CHU Rennes

122 rue Henri Le Guilloux

1335033 Rennes

14 France

15 Tel : +33299284265

16 Fax : +33299284129

17 aude.merdrignac@chu-rennes.fr

19 Grant support: the study did not receive grant support.

20 Conflict of interest: none declared

21 Electronic Word count: 394 words

22 Author contribution: L. Corbière and A. Merdrignac contributed to the conception of the work, drafted the

23 work, gave final approval of the version to be published and agree to be accountable for all aspects of the

24 work in ensuring that questions related to the accuracy or integrity of any part of the work are appropriately

25 investigated and resolved.

26 V. Desfourneaux contributed to the conception of the work, revised it critically for important intellectual

27 content, gave final approval of the version to be published and agree to be accountable for all aspects of

28 the work in ensuring that questions related to the accuracy or integrity of any part of the work are

29 appropriately investigated and resolved. 
A 45-year-old woman presented with bowel obstruction. She underwent a restorative proctocolectomy with ileal-J-pouch-anal anastomosis (IPAA) 3 years previously for „ulcerative colitis-like“ Crohn's disease resistant to medical treatment. On physical examination, she had lower abdominal tenderness and acute intestinal obstruction. Abdominal computed tomography scan revealed small bowel obstruction above a volvulus of the ileal-J-pouch (fig. 1 A and B). Axial maximum intensity projection showed whirling of staple lines of the pouch (fig $1 \mathrm{C}$ ). Endoscopy confirmed a complete whirling of the pouch but endoscopic detorsion failed and was complicated with pouch perforation. Surgical exploration showed pouch ischemia without necrosis. Manual detorsion of the pouch, suture of the perforation and pexy of the pouch were done. Suture was protected with an omental flap and a diverting stoma. Opacification of the pouch and pouch endoscopy two months later showed normal aspect of the pouch. Outcomes of the closure of stoma were uneventful.

\section{Discussion}

Ileal pouch volvulus is a rare complication, only 22 cases reported in a recent review, usually diagnosed by computed tomography [1]. The delay of occurrence was late with a median time to volvulus after IPAA of 36 months as in the present case. Secondary complications (i.e. ischemia, perforation) occurred in $23 \%$ of cases and could lead to pouch excision [1]. Due to the small samples of patients, highlighting risk factors for ileal pouch volvulus is not statistically possible. Absence of adherences responsible of the mobility of the pouch is frequently described without abnormalities of pouch or anastomosis technique. The majority of cases was published in the last 5 years. This fact possibly reflects a large majority of laparoscopically performed IPAA resulting in less peritoneal adherences. The majority of patients were female with larger and wider pelvis than men $[1,2]$. Some authors hypothesized that position of the mesentery of the pouch could facilitate pouch volvulus. Recently, three cases described by Geers et al. had IPAA constructed with mesentery positioned anteriorly [3]. Surgical management with pouch pexy after endoscopic detorsion is the most frequent treatment. The case of a successful endoscopic detorsion without surgical treatment is described in one patient free of relapse after 3-year follow-up [2]. Pouch pexy consists in suturing both efferent and afferent limb of the pouch to the pelvic walls with interrupted multifilament sutures [3]. This bilateral pouch pexy achieves a firm anchoring of the IPAA to avoid recurrence. 
61 1. Jawoosh M, Haffar S, Deepak P, Meyers A, Lightner AL, Larson DW, Raffals LH, Murad MH, Buttar N, 62 Bazerbachi F. Volvulus of the ileal pouch-anal anastomosis: a meta-narrative systematic review of 63 frequency, diagnosis, and treatment outcomes. Gastroenterol Rep. 2019;7(6):403-10.

64 2. Landisch RM, Knechtges PM, Otterson MF, Ludwig KA, Ridolfi TJ. Pouch Volvulus in Patients Having 65 66

3. Geers J, Bislenghi G, D’Hoore A, Wolthuis AM. Surgical Management of an Ileal J-Pouch-Anal 68 Anastomosis Volvulus. Dis Colon Rectum. 2019;62(8):1014- 9. 
69 Figure legend

70 Figure 1: Abdominal computed tomography showed a whirl sign corresponding to the rotation of the ileal-J-

71 pouch around its axis (white arrows, $A$ and $B$ ) confirmed by the rotation of staple lines in maximum intensity 72 projection $(\mathrm{C})$. 

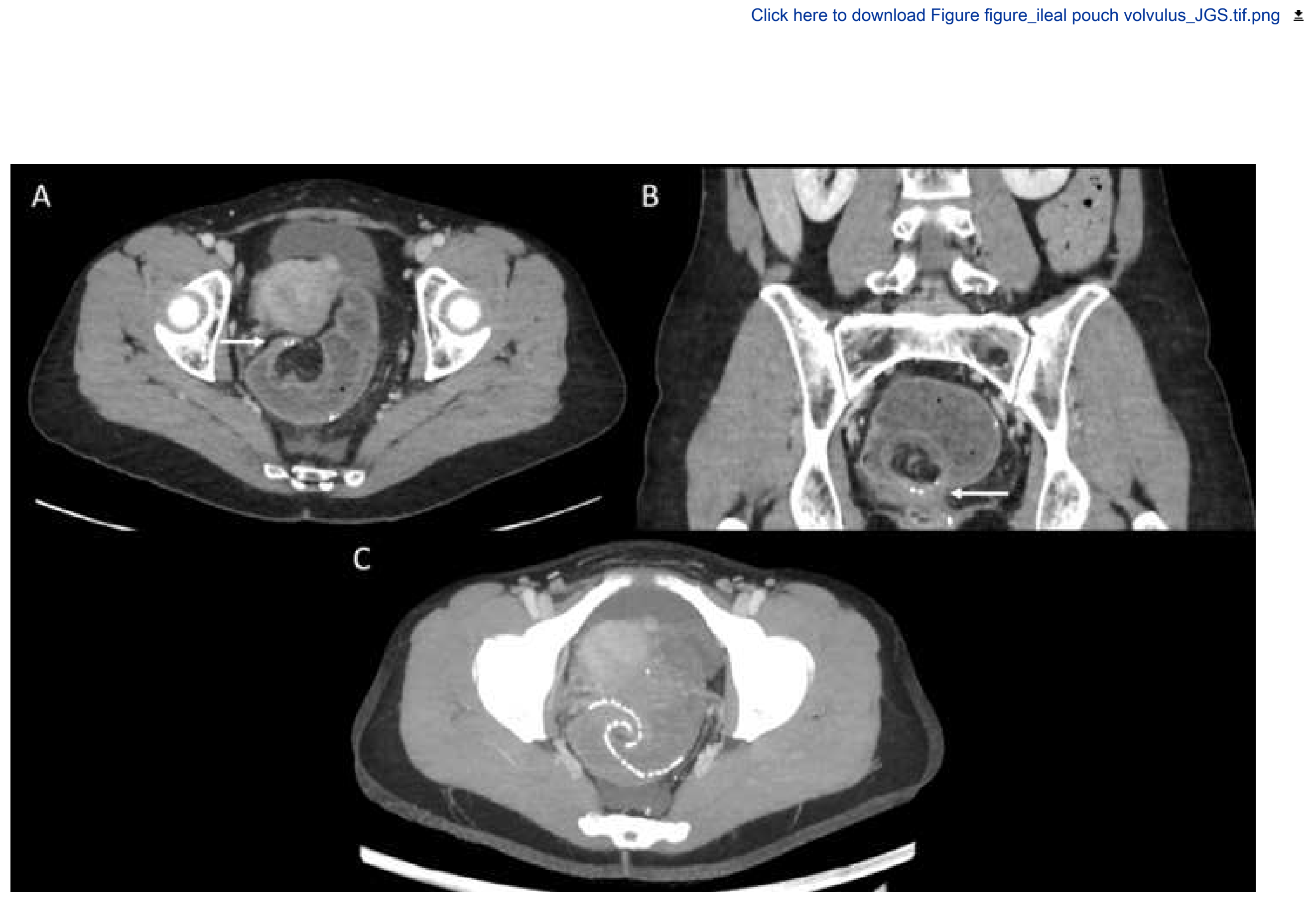

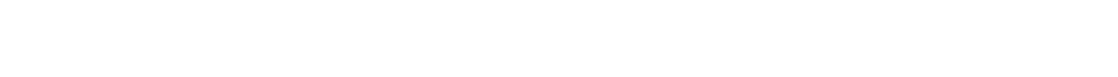

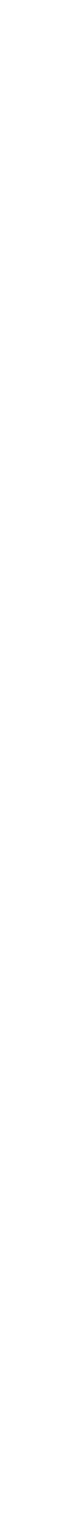

